\title{
Cold shortening decreases the tenderization of Biceps femoris muscle from lambs
}

\author{
Encurtamento do sarcômero diminui o amaciamento do músculo "Biceps femoris" de \\ ovinos
}

\author{
FAUSTO, Daiane Aparecida ${ }^{1 *}$; LIMA, Marcella Arcaro de ${ }^{1}$; RAMOS, Patricia Maloso ${ }^{1}$; \\ PERTILE, Simone Fernanda Nedel ${ }^{1}$; SUSIN, Ivanete ${ }^{1}$; DELGADO, Eduardo Francisquine ${ }^{1}$
}

\author{
${ }^{1}$ Universidade de São Paulo, Escola Superior de Agricultura "Luiz de Queiroz", Departamento de Zootecnia, \\ Piracicaba, São Paulo, Brasil. \\ *Endereço para correspondência: daianefausto@usp.br
}

\section{SUMMARY}

This study evaluates the effects of Normal Shortening (NS) and Cold Shortening (CS) in sarcomere length, Warner-Bratzler shear force (WBS) and tenderization process examined by Myofibrillar Fragmentation Index (MFI). The Biceps femoris muscle from ten Dorper $\mathrm{x}$ Santa Inês lambs was randomly assigned to 1) NS = cooling of the muscle in the carcass for 24 hours in a cold room at $4^{\circ} \mathrm{C}$; or 2) $\mathrm{CS}=$ rapid cooling, in ice bath, of the muscle removed from the carcass immediately after slaughter. Sarcomere Length (SL) was determined in the collected samples 24 hours after slaughter and WBS and MFI in the aging periods ( 1 or 10 days post-mortem). The WBS value of the meat for 1 and 10 days were greater $(\mathrm{P}<0.05)$ for $\mathrm{CS}(4.90 \pm 0.42$ and $3.73 \pm$ $0.42 \mathrm{kgf}$, respectively) than NS $(4.07 \pm 0.36$ and $2.98 \pm 0.38 \mathrm{kgf}$, respectively). There were negative correlations between WBS and SL $(r=$ 0.59 and $\mathrm{r}=-0.69, \mathrm{P}<0.05)$ at 1 and 10 postmortem, respectively. Furthermore, there were positive correlations for MFI and SL ( $r=0.46$ and $\mathrm{r}=0.48, \mathrm{P}<0.05)$ at days 1 and 10 , respectively. These results point to a negative impact of sarcomere cold shortening in the sheep meat tenderization process in the hindlimb muscle.

Keywords: shear force, myofibrillar, proteolysis, meat, Santa Inês

\section{RESUMO}

Foram avaliados os efeitos do encurtamento normal (NS) e encurtamento pelo frio (CS) no comprimento do sarcômero, força de cisalhamento pelo WarnerBratzler (WBS) e no processo de amaciamento analisado pelo índice de fragmentação miofibrilar (MFI). Os músculos Bicep femoris de dez ovinos oriundos do cruzamento Dorper x Santa Inês, foram aleatoriamente designados para: 1) NS: resfriamento do músculo na carcaça por 24 horas na câmara fria a $4^{\circ} \mathrm{C}$ (NS) 2) $\mathrm{CS}$ : resfriamento rápido, em banho de gelo, do músculo removido a partir da carcaça imediatamente após o abate (CS). Comprimento de sarcômero foi determinado nas amostras coletadas 24 horas após o abate e WBS e MFI nos períodos de maturação (1 ou 10 post mortem), em cada tratamento. Os valores de WBS da carne para 1 e 10 dias foram maiores $(\mathrm{P}<0,05)$ para CS $(4,90 \pm 0,42 \mathrm{e}$ $3,73 \pm 0,42 \mathrm{kgf}$, respectivamente) que para NS (4,07 $\pm 0,36$ e $2,98 \pm 0,38 \mathrm{kgf}$, respectivamente). Houve correlação negativa para WBS e comprimento do sarcômero $(r=-0,59$ e $r=-0,69, P<0,05)$ nos dias 1 e 10 de post-mortem. Além disso, foram observadas correlações positivas entre MFI e comprimento do sarcômero $(\mathrm{r}=0,46$ e $\mathrm{r}=0,48, \mathrm{P}<0,05)$ nos dias $1 \mathrm{e}$ 10 , respectivamente. Esses resultados apontam para um impacto negativo do encurtamento do sarcômero no processo de amaciamento de carne em músculo do pernil de cordeiros.

Palavras-chave: força de cisalhamento, miofibrilar, proteólise, carne, Santa Inês 


\section{INTRODUCTION}

Tenderness defined by physical and chemical properties (DELGADO \& SANTOS, 2012) has potential to influence customer satisfaction and willingness to pay a premium, at least for beef (BOLEMAN et al., 1997). It has been shown that this attribute may be also important for Brazilian meat consumers (DELGADO et al., 2006).

Different muscles present variations in tenderness (THOMPSON et al., 2005; HOPKINS et al. 2006), which is a result of differences in stress, chilling rate and electrical stimulation onset (GEESINK et al., 2000; GEESINK et al., 2001; HWANG et al., 2003), as a consequence of their role in rigor mortis.

The rigor mortis process determines the structure of meat (MARSH \& LEET, 1966). During this stage, the shortening of the sarcomere that occurs in the muscle fibers causes muscle stiffness (HWANG et al., 2003), which can affect the tenderness (HOSTETLER et al., 1972; KOOHMARAIE et al., 1996) and it is temperature-dependent (WARNER et al., 2014).

Some evidences point to an impairment of the tenderization process in the aged meat when muscles are removed and submitted to cold shortening (LOCKER, 1985). This may be a result of a lower availability of susceptible sites to proteolytic attack when there is an increased overlap between the thick and thin filaments of the sarcomere. The lower proteolysis of certain myofibrillar proteins during meat tenderization process has been noticed (ENGLAND et al., 2012; WEAVER et al., 2009). However, the results obtained by Wheeler \& Koohmaraie (1999) did not observe interference of sarcomere length in the proteolytic process. Although the latter did not detect interference of sarcomere length on proteolysis, the shear force was higher for treatments with greater shortening of the sarcomere. The relationship between sarcomere length and myofibrillar weakening, that occurs due to proteolysis, has not been reported. Therefore, there is still a controversy about the impact of cold shortening in the extent of tenderization.

Our hypothesis is that cold shortening reduces the extent of tenderization, with persistent negative impact in shear force of extended aged lamb meat. The objective was to evaluate the effects of sarcomere under Normal Shortening (NS) and Cold Shortening (CS) conditions on tenderization process measured by Warner-Bratzler shear force (WBS) and Myofibrillar Fragmentation Index (MFI) at both post-rigor and extended aging period.

\section{MATERIAL AND METHODS}

The research was conducted at the University of Sao Paulo and procedures for using animals were approved by the Internal Committee for Animal Experimentation (protocol 146.352, CEP FZEA).

Samples from 10 carcasses of crossbred Dorper x Santa Inês lambs, at about 151 days of age, average body weight of $34.33 \mathrm{~kg} \pm 0.58$, and carcass weight of $16.93 \mathrm{~kg} \pm 0.30$ were used to perform the analysis. The slaughter was carried out at the experimental slaughterhouse of the Faculty of Animal Science and Food Engineering in the city of Pirassununga, São Paulo (FZEA/USP). During the 
slaughter, hot carcasses were measured (the total length) and weighted. The Biceps femoris muscles from the right side of the carcass of each animal were removed, identified, and packaged on plastic bags and assigned to ice treatment immediately after its excision to cause cold shortening of the sarcomere (CS) - treatment consisted of dipping the samples in cooler containing icy water at $0^{\circ} \mathrm{C}$ for 2 hours. After the treatment, the muscles were removed and placed in a cold room at $4^{\circ} \mathrm{C}$ for 24 hours after slaughter.

The comparative treatment did not intend to cause the excessive shortening of the sarcomere, called Normal Shortening (NS). Therefore, the muscles were kept on the left side of the carcass that was hanged by Achilles tendon in a cold room at $4^{\circ} \mathrm{C}$ for 24 hours after slaughter. After this time, the muscles Biceps femoris from the left side were removed, identified, measured and packaged. All samples were packed in a cooler to be transported to the Laboratory of Animal Anatomy and Physiology (ESALQ / USP), in Piracicaba, São Paulo, where the remaining analyses were performed. Once in the Laboratory, half of the samples, from both shortening treatments, were immediately frozen for posterior analysis, which constituted the 24 hours' samples (T1). The other half was aged for 9 more days from 4 to $6^{\circ} \mathrm{C}$, which constituted the samples aged for 10 days (T10). Samples from both postmortem aging periods were subjected to evaluations of Warner-Bratzler shear force (WBS) and Myofibrillar Fragmentation Index (MFI).

For WBS evaluation, one steak aged for each of the aging periods ( 1 or 10 days post-mortem) was thawed in a refrigerator for 18 hours cooked in electric grill (SSE50, Edanca, São Paulo, Brazil) until they reach an internal temperature of $71^{\circ} \mathrm{C}$ to perform the objective tenderness. After cooking, the steak was cooled for 24 hours and subsequently, 6 cylindrical samples were removed with $1.27 \mathrm{~cm}$ diameter, measuring approximately $2 \mathrm{~cm}$ in length, taken parallel to the long axis of the muscle fibers (AMSA, 1995; WHEELER et al., 1997). Shear force was determined in a Warner-Bratzler shear (WBS) machine (GR manufacturing CO Collins, LN Model: BFG 500N Basic force gauge, Mecmesin brand - series: 66502). The cylinders removed from the cooked steaks were completely sheared in its geometric center and the value is expressed in kilogram force (kgf). After WBS measurements, it was used to determine the Myofibrillar Fragmentation Index (MFI) in the cooked meat.

The Myofibrillar Fragmentation Index (MFI) in the raw and cooked meat from shear force analysis, was determined according to the methodology proposed by Culler et al. (1978) and the sarcomere length analysis was performed according to Cross et al. (1981). For sarcomere length, to represent the muscle, samples $(0.5 \times 0.5 \times 1.5 \mathrm{~cm})$ of 5 anatomical locations (Figure 1) of the steak were immersed in $5 \%$ glutaraldehyde solution and kept in the refrigerator for 4 hours at $4^{\circ} \mathrm{C}$. The solution was replaced by a Sucrose $0.2 \mathrm{M}$ solution (KOOLMEES et al., 1986), and the samples were homogenized in Ultraturrax (IKA T25 digital, model T25 DS1 series: 03.323948). After mixing, 10 different measurements were performed on each slide for every location of each muscle. The determinations were carried out with the aid of Nikon Eclipse 80i microscope, lens with $100 \mathrm{x}$ magnification (Figure 1). The lengths were measured with a computer program from Nikon Elements F. 


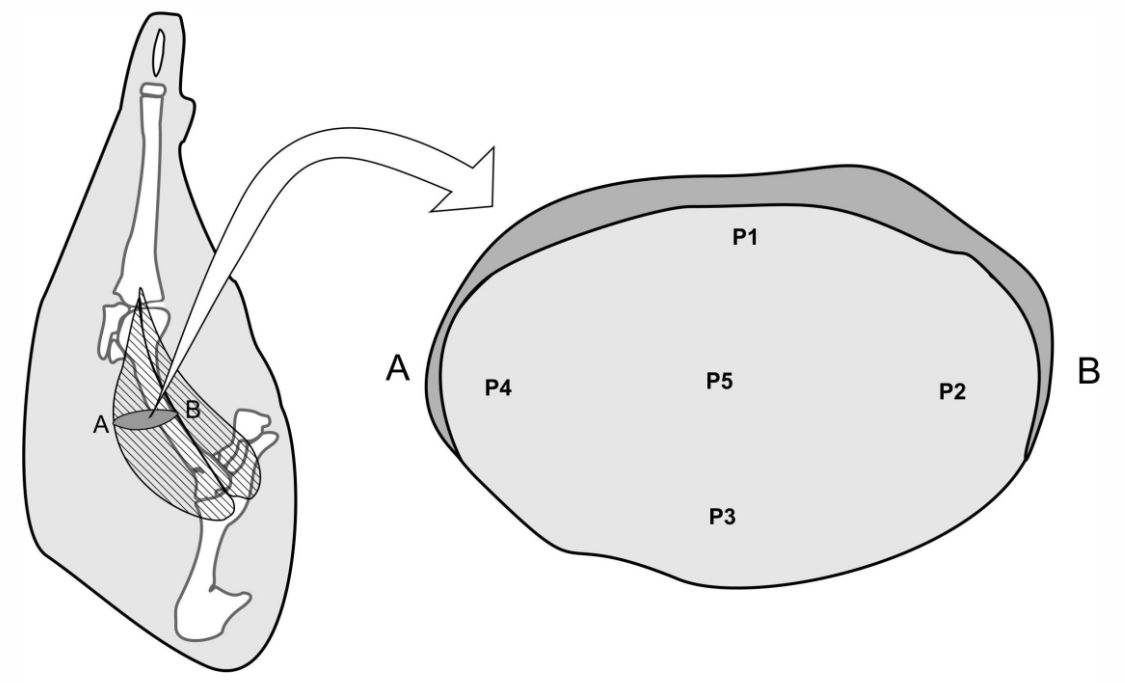

Figure 1. Scheme of sampling for sarcomere length measure in 5 locations (P1 - lateral; P2 - caudal; P3 - medial; P4: cranial; P5: center) in the Biceps femoris muscle from lambs subjected to different cooling regimes

The statistical analysis for WBS and MFI were performed considering completely randomized design with repeated measurements for samples submitted to two aging times (T1 and T10) and two types of cold shortening of the sarcomere, with the model: $\mathrm{y}_{i j k}=\mu+\mathrm{C}_{i}+\mathrm{T}_{j}+(\mathrm{CT})_{i j}+\mathrm{CL}_{\mathrm{ijk}}+$ $\varepsilon_{\mathrm{ijk}}$, in that $\mathrm{y}_{i j k}$ is the effect of the $\mathrm{i}^{\text {th }}$ level of types of cold shortening of the sarcomere, $\mathrm{j}^{\text {th }}$ level of aging times and $\mathrm{k}^{\text {th }}$ repetition; $\mu$ is the overall mean; $\tau_{\mathrm{i}}$ is the effect of the types of cold shortening of the sarcomere; $T_{j}$ is the effect of $\mathrm{j}^{\text {th }}$ aging times; $(\mathrm{CT})_{i j}$ is the interaction effect between $\mathrm{C}_{i}$ and $\mathrm{T}_{j}$, $\mathrm{CL}_{\mathrm{ijk}}$ is the covariate carcass length, $\varepsilon_{\mathrm{ijk}}$ is the residual error. The traits of sarcomere length was studied only in T1, and the statistical model for these traits had only the treatment types of cold shortening of the sarcomere and the covariate carcass length. The variance analyses was performed using the method of Restricted Maximum Likelihood (REML), by MIXED procedure
(SAS Inst. Inc., Cary, NC). Due to repeated measures in time, for WBS and MFI were compared with different covariance matrix, and the better model was selected by Bayesian Information Criteria (BIC). The residuals attended the assumptions of normality and homogeneity of variance. The treatments and interactions that had significant effect for test $\mathrm{F}(\mathrm{P}<0.05)$ were analyzed by Tukey test, and the differences were considered significate when $\mathrm{P}<0.05$. We calculated correlation among all traits, by CORR procedure of software SAS.

\section{RESULTS AND DISCUSSION}

The positions sampled (Figure 1) presented the same pattern of sarcomere shortening due to the cooling regimes (Table 1). This might be associated to the Biceps femoris anatomical position and 
the hanging of the carcass by the Achilles tendon, which would result of a uniform grip of the whole muscle that remained in the carcass, limiting different shortening at the anatomical positions sampled.

Muscle samples removed from the carcass after rigor mortis (NS), which restrained the muscle during rigor, showed an average shortening of $19 \%$ to the normal sarcomere length at rest (Table 1). Even though the shortening was not considered detrimental for tenderness, the muscle presented short sarcomeres, varying from 1.61 to 1.70 (Table 1) due to fast chilling rates observed in small carcass of low fatness, which corroborate with average sarcomere length of 1.62 for Biceps obtained by conditioning at $0^{\circ} \mathrm{C}$ to $1^{\circ} \mathrm{C}$ for 2 days (BOUTON et a., 1973b). Those results for CS e NS also corroborate with average sarcomere length of the shortened (1.36) and control $(1.67-1.70)$ groups for lamb Longissimus dorsi (WHEELER \& KOOHMARAIE, 1999).

Table 1. Sarcomere length of Biceps femoris muscle, from Dorper $\mathrm{x}$ Santa Inês crossbred lambs, subjected to different post-mortem cooling regimes

\begin{tabular}{lccccc}
\hline & & Cold shortening & Normal shortening & $\mathrm{P}<$ & Covariate* $^{*}$ \\
\hline & "Location P 1 & $1.36 \pm 0.04$ & $1.62 \pm 0.04$ & 0.001 & 0.08 \\
& ${ }^{\#}$ Location P 2 & $1.39 \pm 0.05$ & $1.63 \pm 0.06$ & 0.006 & 0.76 \\
& ${ }^{\#}$ Location P 3 & $1.32 \pm 0.02$ & $1.67 \pm 0.02$ & 0.001 & 0.12 \\
& ${ }^{\#}$ Location P 4 & $1.32 \pm 0.02$ & $1.69 \pm 0.02$ & 0.001 & 0.81 \\
Sarcomere $(\mu \mathrm{m})$ & "Location P 5 & $1.31 \pm 0.03$ & $1.62 \pm 0.03$ & 0.001 & 0.25 \\
& Average & $1.35 \pm 0.03$ & $1.65 \pm 0.03$ & 0.001 & 0.86 \\
& Maximum & $1.49 \pm 0.03$ & $1.70 \pm 0.04$ & 0.001 & 0.10 \\
& Minimum & $1.26 \pm 0.01$ & $1.61 \pm 0.02$ & 0.001 & 0.40 \\
& Muscle length $(\mathrm{cm})$ & $18.68 \pm 0.68$ & $22.34 \pm 0.76$ & 0.003 & 0.08 \\
\hline
\end{tabular}

*Carcass frame size was not significant covariate for this feature. Normal shortening: cooling of the muscle in the carcass for 24 hour at cold room at $4^{\circ} \mathrm{C}(\mathrm{NS})$; Cold shortening: rapid cooling, in ice bath, of the muscle removed from the carcass immediately after slaughter. ${ }^{\#}$ Sarcomere length values was collected in 5 locations in the Biceps femoris muscle from lambs subjected to different cooling regimes (P1 - lateral; P2 caudal P3 - medial P4: cranial; P5: center).

After being removed from the carcass and treated with ice (CS), it was expected that the muscles would experience a shortening of about $30 \%$ of the resting sarcomere length, reaching a length between 1.30 to $1.50 \mu \mathrm{m}$, considering that the sarcomere at rest measures between 2.1 to $2.2 \mu \mathrm{m}$ (WHEELER \& KOOHMARAIE, 1999). The minimum, average, and maximum sarcomere length values found on the 5 locations in the muscle were within this range (Table 1), with shortening of the order of 40, 36 and 29\%, respectively (Table 1). Similar results were found by Wheeler \& Koohmaraie (1999), who observed sarcomere shortened to an average length between 1.36 and $1.45 \mu \mathrm{m}$. This observation proves that the cooling treatment given to these samples was effective in shortening the sarcomere to the proportion of the length that has been reported to negatively affect the tenderness 
(MARSH \& LEET, 1966). The muscle length at CS was about $83.62 \%$ of the length of the muscle that remained in the carcass, which shows a good agreement with the data from the sarcomere length, where CS group was $81.82 \%$ of the NS.

The results indicate that cold shortening process can impact tenderness at day 1 post-mortem and the tenderization process during aging (Table 2). Marsh \& Leet (1966), found that shear force is directly affected by the muscle shortening, so, the greater the shortening the higher the force required to shear the muscle. Those results also agree with Hostetler, Link, Landmann \& Fitzhugh (1972), Bouton et al. (1973 a, b). Moreover, lower temperature during rigor mortis resulted in a negative impact between sarcomere length and shear force values on lamb Longissimus muscle (GEESINK et al., 2000; WHEELER \& KOOHMARAIE, 1999). However, those authors did not find negative impact of sarcomere length in post-mortem proteolysis during the aging period.

Table 2. Meat shear force* from Biceps femoris muscle, from crossbred Dorper x Santa Inês lambs, subjected to different post-mortem cooling regimes and aging times

\begin{tabular}{|c|c|c|c|}
\hline Treatment (Treat) & Cold shortening & Normal shortening & $<\mathrm{P}$ \\
\hline Aging (A) & \multicolumn{2}{|c|}{ Shear Force (kgf) } & \\
\hline T1 & $4.90^{c} \pm 0.42$ & $4.07^{\mathrm{ab}} \pm 0.36$ & - \\
\hline $\mathrm{T} 10$ & $3.73^{b} \pm 0.42$ & $2.98^{\mathrm{a}} \pm 0.38$ & - \\
\hline \multicolumn{4}{|l|}{ Effects } \\
\hline Treatment (Treat) & - & - & 0.02 \\
\hline Aging (A) & - & - & 0.01 \\
\hline Treat x A & - & - & 0.90 \\
\hline
\end{tabular}

Negative correlation values were found between the WBS and sarcomere length at day 1 (Table 3). Those correlations were still observed after 10 days postmortem. Moreover, correlation coefficient for minimum and average sarcomere length with WBS at an intermediate and higher level than observed for maximum sarcomere length points to the importance of shorter sarcomeres to detect the related
WBS changes, especially for extended aging periods. Greater shear force for shortened sarcomeres even after the 10 days aging was reported before (WHEELER \& KOOHMARAIE, 1997). Although, those authors were not able to demonstrate that shortened sarcomere affect Troponin $\mathrm{T}$ and Desmin proteolysis after 10 days. 
Table 3. Correlation between shear force (WBS), Myofibrillar fragmentation index (MFI) of cooked and raw meat with sarcomere length from Biceps femoris (T1 and T10) from crossbred Dorper x Santa Inês lambs subjected to different aging times

\begin{tabular}{lcccccc}
\hline & \multirow{2}{*}{ WBS } & \multirow{2}{*}{ MFI raw } & \multirow{2}{*}{ MFI cooked } & \multicolumn{3}{c}{ Sarcomere length } \\
\cline { 5 - 7 } & & & & Average & Maximum & Minimum \\
\hline T 1 & & & & & & \\
\hline WBS & 1 & $-0.3991^{*}$ & 0.2478 & $-0.5902^{*}$ & $-0.4768^{*}$ & $-0.5322^{*}$ \\
MFI raw & - & 1 & $-0.3639^{*}$ & $0.4608^{*}$ & $0.3352^{*}$ & $0.5134^{*}$ \\
MFI cooked & - & - & 1 & -0.0236 & 0.1239 & -0.0837 \\
\hline T 10 & & & & & & $-0.6480^{*}$ \\
\hline WBS & 1 & $-0.4645^{*}$ & 0.0391 & $-0.6953^{*}$ & $-0.4539^{*}$ & $0.3966^{*}$ \\
MFI raw & - & 1 & 0.0228 & $0.4881^{*}$ & $0.4596^{*}$ & 0.2442 \\
MFI cooked & - & - & 1 & 0.2566 & $0.3687^{*}$ & 0.246 \\
\hline
\end{tabular}

When evaluated the correlations between WBS and Myofibrillar Fragmentation Index (MFI) of raw meat, the negative correlation found (Table 3) indicates that the smaller fragmentation index has higher shear force values, which corroborates the inverse relationship between shear force and Myofibrillar Fragmentation Index (OLSON et al., 1976). Furthermore, MFI and sarcomere length presented a positive correlation, which reinforces the idea of some limitation of myofibrillar weakening when there is shortening. Those positive correlations agree with slowed Troponin $\mathrm{T}$ proteolysis by $\mu$-calpain in the myofibrillar fraction caused by sarcomere cold-shortening (WEAVER et al., 2009). The degradation of troponin $\mathrm{T}$ is a marker of tenderization (IWASAKI et al., 2016) and therefore it is related with myofibrillar weakening (HUFFLONERGAN et al., 1996).

These data emphasize the importance of sarcomere length to tenderness and the relative contribution of sarcomere length to proteolysis measured by MFI and tenderness variations after aging (T10).
There remains a question whether those differences would be sufficient to influence the consumer satisfaction.

We conclude that the muscle samples that were submitted to cold shortening, showed some decrease in myofibrillar degradation and tenderness even after aging, evidenced by high shear force values. Therefore, there was a negative effect of cold shortening in the process of tenderization of Biceps femoris muscle from sheep.

\section{ACKNOWLEDGEMENT}

The University of São Paulo for undergraduate student scholarship to the second author (Grant: August/2012 until July/2013). We thank Dr. Gilberto José de Moraes and his PhD student Raphael de Campos Castilho, from the Department of Entomology and Acarology (ESALQ/USP), for helping us with the use of the Nikon microscope and software in the sarcomere length determinations. We also would like to acknowledge the Departament of Agri-food Industry, Food and Nutrition for the assistance of Luiz Carlos Rodrigues in preparing the figure for this paper. 


\section{REFERENCES}

AMERICAN MEAT SCIENCE ASSOCIATION - AMSA. Meat evaluation handbook. Savoy, 1995. $161 \mathrm{p}$.

BOLEMAN, S.J.; BOLEMAN, S.L.; MILLER, R.K .; TAYLOR, J.F.; CROSS, H.R.; WHEELER, T.L.; KOOHMARAI, M.; SHACKELFORD, S.D.; MILLER, M.F.; WEST, R.L., JOHNSON, D.D.; SAVELL, J.W. Consumer evaluation of beef of known categories of tenderness. Journal of Animal Science, v.75, p.1521-1524, 1997.

BOUTON, P.E.; FISHER, A.L.; HARRIS, P.V.; BAXTER, R.I. A comparison of the effects of some postslaughter treatments on the tenderness of beef. Journal of Food Technology, v.8, p.39-49, 1973a.

BOUTON, P.E.; HARRIS, P.V.; SHORTHOSE, W.R.; BAXTER, R.I.A. Comparison of the effects of aging, conditioning and skeletal restraint on the tenderness of mutton. Journal of Food Technology, v.38, p.932-936, 1973 b.

CROSS, H.R.; WEST, R.L.; DUTSON, T.R.. Comparison of methods for measuring sarcomere length in beef semitendinosus muscle. Meat Science, v.5, p.261-266, 1981.

CULLER, R.D.; PARRISH JR, F.C.; SMITH, G.C.; CROSS, H.R. Relationship of myofibril fragmentation index to certain chemical, physical and sensory characteristics of bovine Longissimus muscle. Journal of Food Science, v.43, p.1177-1180, 1978.
DELGADO, E.F.; AGUIARII, A.P.; ORTEGAIII, E.M.M.S.; SPOTO, M.H.F.; CASTILLO, C.J.C. Brazilian consumers' perception of tenderness of beef steaks classified by shear force and taste.

Science Agricola, v.63, n.3, p.232-239, 2006.

DELGADO, E.F.; SANTOS, C.C. Fatores anteriores e posteriores ao abate que influenciam a qualidade de carne. In: PIRES, A.V. Bovinocultura de corte. Piracicaba: Fealq, 2012. p.1283-1304.

ENGLAND, E.M.; FISHER, K.D.; WELLS, S.J.; MOHRHAUSER, D.A.; GERRARD, D.E.; WEAVER, A.D.

Postmortem titin proteolysis is influenced by sarcomere length in bovine muscle.

Journal of Animal Science, v.90, p.989995, 2012.

GEESINK, G.H.; BEKHIT, A.E.D.; BICKERSTAFFE, R. Rigor temperature and meat quality charateristics of lamb longissimus muscle. Journal of Animal Science, v.78, n.11, p.2842-2848, 2000.

GEESINK, G.H.; MAREKO, M.H.D.; MORTON, J.D.; BICKERSTAFFE, R. Effects of stress and high voltage electrical stimulation on tenderness of lamb m. longissimus. Meat Science, v.57, p.265-271, 2001.

HWANG, I.H.; DEVINE, C.E.; HOPKINS, D.L. The biochemical and physical effects of electrical stimulation on beef and sheep meat tenderness. Meat Science, v.65, p.677-691, 2003. 
HOSTETLER, R.L.; LINK, B.A.; LANDMANNL, W.A.; FITZHUGH, H.A. Effect of carcass suspension on sarcomere length and shear force of some major bovine muscle. Journal of Food Science, v.37, p.132-135, 1972.

HOPKINS, D.L.; HEGARTY, R.S., WALKER, P.J.; PETHICK, D.W. Relationship between animal age, intramuscular fat, cooking loss, $\mathrm{pH}$, shear force and eating quality of aged meat from sheep. Australian Journal of Experimental Agriculture, v.46, p.879884, 2006.

HUFF-LONERGAN, E.; MITSUHASHI, T.; BEEKMAN, D.D.; PARRISH, JR., F.C.; OLSON, D.G.; ROBSON, R.M. Proteolysis of Specific Muscle Structural Proteins by $\mathrm{m}$-Calpain at Low $\mathrm{pH}$ and Temperature Is Similar to Degradation in Postmortem Bovine Muscle. Journal of Animal Science, v.74, p.993-1008, 1996.

IWASAKI, T.; TANIGUCHI, H; HASEGAWA, Y.; MAEDAB, N.; YAMAMOTOA, K. A novel method for monitoring troponin $\mathrm{T}$ fragment from rabbit skeletal muscle during aging using quartz crystal microbalance. Journal of the Science of Food and Agriculture, v.96, p.3944-3949, 2016.

KOOLMEES, P.A.; KORTEKNIE, F., SMULDERS, F.J.M. Accuracy and utility of sarcomere length assessment by laser diffraction. Food Microstructure, v.5, p.71-76, 1986.

KOOHMARAIE, M. Biochemical Factors Regulating the Toughening Tenderization Processes of Meat. Meat Science, v.43, p.193-201, 1996.
KOOHMARAIE, M.; DOUMIT, M.E.; WHEELER, T.L. Meat toughening does not occur when rigor shortening is prevented. Journal of Animal Science, v.74, p.2935-2942, 1996.

LOCKER, R.H. Cold-induced toughness of meat. In: PEARSON, A.M..; DUTSON, T.R. (Eds.). Advances in meat research. Electrical stimulation. Connecticut: AVI Publishing Company, 1985. p.1-45.

MARSH, B.B.; LEET, N.G. Studies in meat tenderness. III. The effects of cold shortening on tenderness. Journal Food Science. v.31, p.450, 1966.

OLSON, D.G.; PARRISH JR, F.C.; STROMER, M.H. Myofibrillar fragmentation and shear resistance of three bovine muscles during postmortem storage. Journal of Food Science, v.41, p.1036-1041, 1976.

THOMPSON, J.M.; HOPKINS, D.L.; SOUZA, D.N.D'.; WALKER, P.J.; BAUD, S.R.; PETHICK, D.W. The impact of processing on sensory and objetive measurements of sheep meat eating quality. Australian Journal of Experimental Agriculture, v.45, p.561573, 2005.

WARNER, R.D.; KERR, M.; KIM, Y.H.B.; GEESINK, G. Pre-rigor carcass stretching counteracts the negative effects of high rigor temperature on tenderness and water-holding capacity - using lamb muscles as a model. Animal Production Science, v.54, p.494-503, 2014. 
WEAVER, A.D.; BOWKER, B.C.;

GERRARD, D.E. Sarcomere length influences $\mu$-calpain-mediated proteolysis of bovine myofibrils. Journal of Animal Science, v.87, p.2096-2103, 2009.

WHEELER, T.L.; KOOHMARAIE, M. The Extent of Proteolysis Is Independent of Sarcomere Lenght in Lamb Longissimus and Psoas Major. Journal of Animal Science, v.77, p.2444-2451, 1999.

WHEELER, T.L.; SHACKELFORD, S.D.; JOHNSON, L.P.; MILLER, M.F.; MILLER, R.K.; KOOHMARAIE, M. A comparison of Warner-Bratzler shear force assessment within and among institutions. Journal of Animal Science, v.75, p.2423-2432, 1997.

Data de recebimento: 04/03/2016

Data de aprovação: 15/02/2017 